\title{
An Assessment of the Influence of Host Species, Age, and Thallus Part on Kelp-Associated Diatoms
}

\author{
Ntambwe Albert Serge Mayombo ${ }^{1, * \mathbb{C}}$, Roksana Majewska ${ }^{2,3}$ and Albertus J. Smit ${ }^{1,4, *(\mathbb{C}}$ \\ 1 Department of Biodiversity and Conservation Biology, University of the Western Cape, \\ Bellville 7535, South Africa \\ 2 Unit for Environmental Sciences and Management, School of Biological Sciences, North-West University, \\ Potchefstroom 2520, South Africa; roksana.majewska@nwu.ac.za \\ 3 South African Institute for Aquatic Biodiversity (SAIAB), Grahamstown 6140, South Africa \\ 4 Elwandle Coastal Node, South African Environmental Observation Network (SAEON), \\ Port Elizabeth 6013, South Africa \\ * Correspondence: sergemayombo@yahoo.fr (N.A.S.M.); ajsmit@uwc.ac.za (A.J.S.)
}

Received: 26 June 2020; Accepted: 17 August 2020; Published: 8 October 2020

\begin{abstract}
Diatom community composition and abundances on different thallus parts of adult and juvenile specimens of Ecklonia maxima and Laminaria pallida were examined in False Bay, South Africa, using light and scanning electron microscopy. Altogether, 288 thallus portions were analysed. Diatom abundances ranged from 0 to 404 cells $\mathrm{mm}^{-2}$ and were generally higher on E. maxima and juvenile thalli than $L$. pallida and adult specimens. Moreover, diatom abundances differed between the various thallus parts, being highest on the upper blade and lowest on the primary blade. A total of 48 diatom taxa belonging to 28 genera were found. Gomphoseptatum Medlin, Nagumoea Witkowski and Kociolek, Cocconeis Ehrenberg, and Navicula Bory were the most frequently occurring genera, being present in $84 \%, 65 \%, 62.5 \%$, and $45 \%$ of the analysed samples, respectively. Among these, Cocconeis and Gomphoseptatum were the most abundant, contributing 50\% and $27 \%$ of total diatom cells counted collectively across all samples. Permutational multivariate analysis of variance (PERMANOVA) revealed that all investigated main factors (kelp species and age and thallus part), as well as their two- and three-way interactions, except for the interaction between the host species and age, were significant. The high residual variance $(72 \%)$ indicated that the sum of other unexamined factors contributed the largest component of the variation observed in the kelp-associated diatom communities, and grazing and possible defence strategies utilised by kelps are proposed as processes playing an important role in the structuring of epiphytic diatom communities. Possible endophytism of tissue-boring diatoms colonizing both kelp species is briefly discussed.
\end{abstract}

Keywords: epiphytic diatoms; diatom abundances; Cocconeis; Gomphoseptatum; macroalgae; Ecklonia maxima; Laminaria pallida; thallus part; multivariate analyses; False Bay

\section{Introduction}

Kelp forests thrive along most rocky shorelines in temperate and polar waters across the globe [1]. These dynamic biogenic habitats host large biodiversity of flora and fauna, forming the basis of complex marine food webs and providing, directly and indirectly, numerous valuable ecosystem services to humans, including food provision, the supply of raw materials for industry, atmospheric gas balance and climate regulation, disturbance prevention (flood buffering and storm protection), and nutrient cycling [1,2]. Kelp thalli constitute suitable substrata for the growth of various epiphytic macro- and micro-organisms, further contributing to the productivity of coastal environments worldwide [3]. Among epiphytic microalgae associated with kelps and other seaweeds, diatoms, which are thought 
to be responsible for at least $40 \%$ of oceanic primary production, often form the most diverse and abundant surface-associated communities [4-9].

Macroalgae may interact with epiphytes on their surfaces by either enhancing or deterring their growth $[5,10]$. Those effects may be species-specific [10-13], may be related to the host morphology $[6,7,10,14]$ or the thallus part $[10,11,15]$, and may change throughout the host organism life cycle [16]. For example, nutrients released through the surface of dying Cladophora sp. may favour the settlement and proliferation of epiphytic diatom communities [5]. The level of epiphytic colonisation in Ecklonia radiata (C.Agardh) J.Agardh was positively correlated with the exposure time of the various thallus parts to the marine environment, and thus was related to the thallus age [17]. The shedding of the outer layer of the thallus (epithallus), which is often an effective mechanism of reducing biofouling, has been reported from a number of macroalgae [18-23]. Shedding may be intensified in young, fast-growing tissues, promoting gradients in the distribution of epiphytes on different parts of the host macroalgal thallus $[19,24,25]$. Other defence strategies against epiphytes observed in macroalgae involve the production of various antimicrobial compounds [26], which may vary across the macroalgal thallus. For example, various parts of Ascophyllum nodosum (Linnaeus) Le Jolis secreted significantly different concentrations of tannin that seemed to affect the epiphytic microorganisms [27].

Diatoms are known for their excellent bio-indication properties and have long been used in biomonitoring studies worldwide [28-30]. In the future, kelp-associated diatoms may serve as indicators of the multifactorial changes occurring in the most vulnerable coastal ecosystems. However, currently, little is known about either the kelp-associated diatom community composition or the interplay between biotic and abiotic factors affecting the epiphytic assemblages. This knowledge is required before accurate diatom-based indices of the marine habitat health can be developed. In South Africa, studies investigating diatoms associated with local seaweeds are sparse, with most being purely floristic surveys dating back to the 1970s [31-33]. The present study aimed to assess the influence of host macroalga species, age, and thallus part on diatoms epiphytic on two common and commercially valuable kelp species, Ecklonia maxima (Osbeck) Papenfuss and Laminaria pallida Greville, providing new information on abundances and composition of kelp-associated diatom communities as well as seaweed-diatom interactions.

\section{Materials and Methods}

\subsection{Study Site}

Kelp specimens analysed in this study were collected on 24 July 2017 by scuba diving near Miller's Point ( $\left.34.2198^{\circ} \mathrm{S}, 18.6400^{\circ} \mathrm{E}\right)$, False Bay, South Africa (Figure 1). False Bay is a $33 \mathrm{~km}$ wide indentation of the coast located between Cape Point and Cape Agulhas. The area constitutes a transition zone between warmer southern waters and colder western waters from the Benguela Current system [34,35]. This coastal transition zone supports abundant kelp forests, with the understorey and intertidal seaweed flora composed of species typical of both the cool west coast and the warmer south coast [36]. Temperatures within the bay are higher than on the west side of the Cape Peninsula because of solar heating of the shallow bay waters. At Miller's Point, where the specimens were collected, the seafloor was mainly rocky, with patches of sand present between the kelp clusters and pavements of encrusting coralline red algae covering the hard surfaces. The maximum depth at the sampling site was $10 \mathrm{~m}$ and the water temperature recorded in situ at the time of collection was $15^{\circ} \mathrm{C}$ (with maximum and minimum temperatures recorded during winter 2017 being $15.2^{\circ} \mathrm{C}$ and $12.2^{\circ} \mathrm{C}$, respectively). 


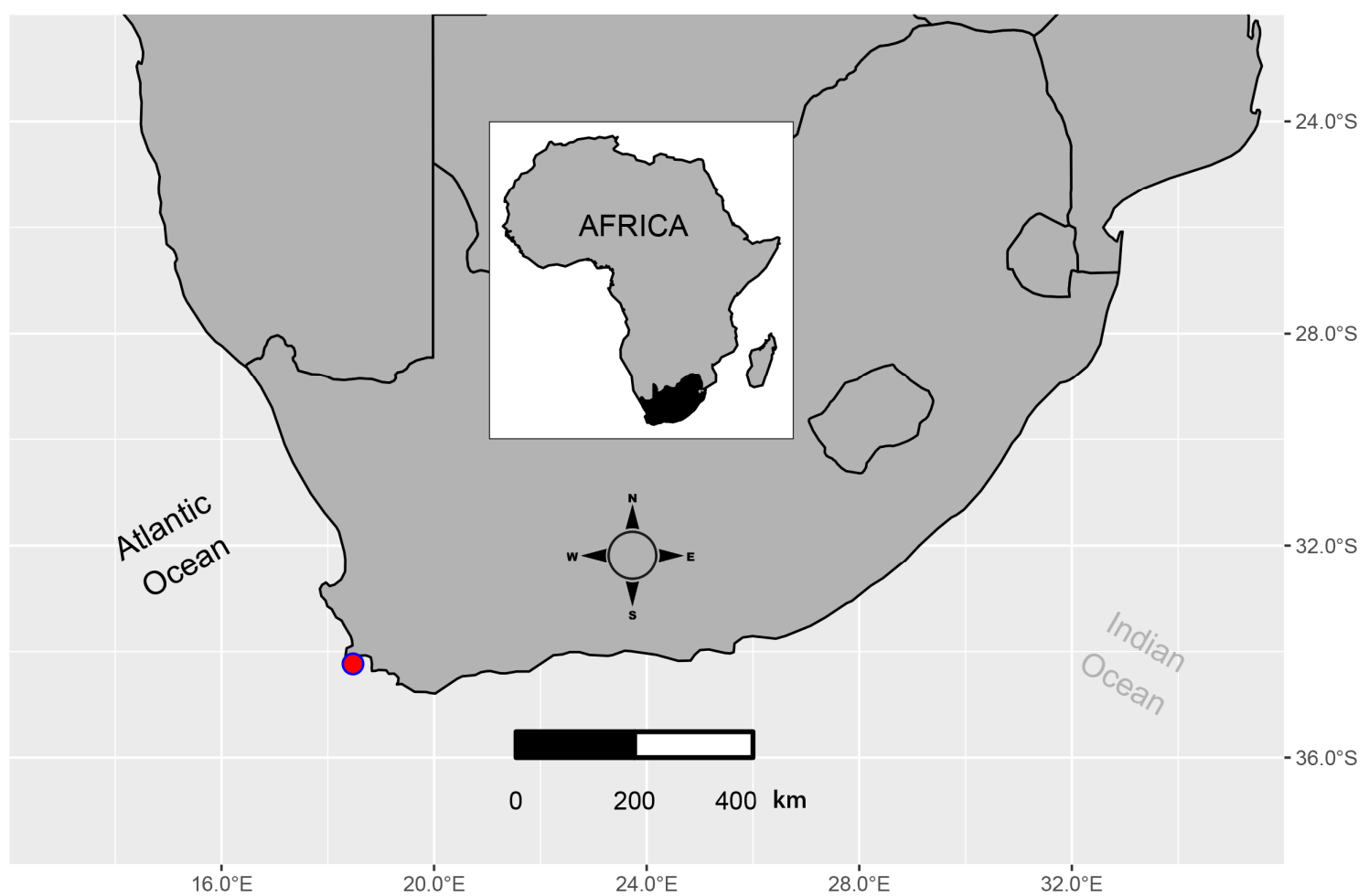

Figure 1. Map of South Africa showing the location of Miller's Point, False Bay, South Africa (red point).

\subsection{Material Collection}

Four juvenile (less than $1.5 \mathrm{~m}$ long) and four adult (more than $3 \mathrm{~m}$ long) specimens of each of Ecklonia maxima and Laminaria pallida were collected from arbitrarily chosen spots within a sampling area of ca. $10 \mathrm{~m}^{2}$. Each thallus was separated into six morphologically and functionally different parts, including the holdfast, lower stipe, upper stipe, primary blade, lower blade, and upper blade (Figure 2). Each part was placed in a separate plastic container and fixed in a $4 \%$ formaldehyde solution in filtered seawater immediately after collection. Subsequently, the samples were processed in the laboratories of the Department of Biodiversity and Conservation Biology of the University of the Western Cape (UWC, Cape Town, South Africa) and the Unit for Environmental Sciences and Management at North-West University (NWU, Potchefstroom, South Africa). 


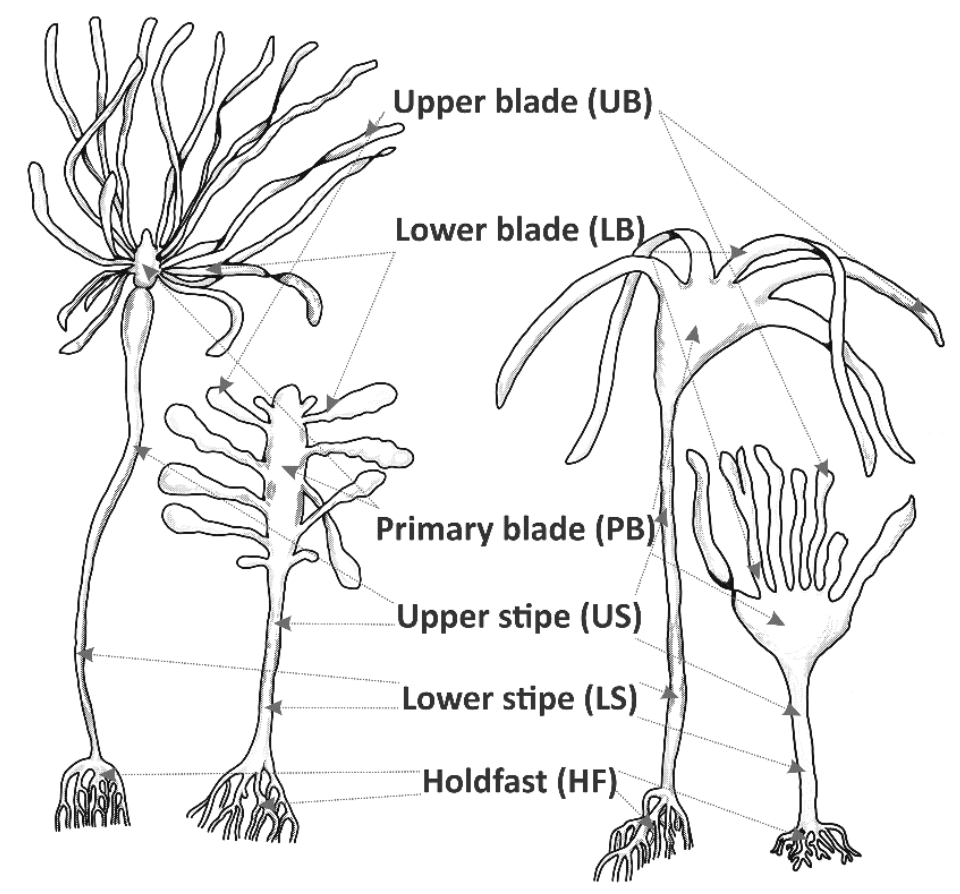

Figure 2. Schematic representation of adult and juvenile specimens of Ecklonia maxima and Laminaria pallida showing different parts of the thalli.

\subsection{Sample Processing and Microscopy}

From each kelp sample, three arbitrarily chosen $1 \mathrm{~cm}^{2}$ portions (referred to hereafter as "subsamples") were cut from the surface layer. Macroscopically, the surface of the collected thalli appeared smooth and even, with no apparent signs of diatom biofouling. The subsamples were dehydrated by immersion in ethanol solutions at increasing concentrations, as described in Mayombo et al. [23]. Subsequently, the specimens were processed in an HCP-2 critical point dryer (Hitachi Koki Co., Tokyo, Japan), mounted on $13 \mathrm{~mm}$ aluminium stubs with adhesive carbon tape, and sputter-coated with gold/palladium (Au/Pd) using a Q150T ES sputter coater (Quorum Technologies Ltd., Laughton, East Essex, United Kingdom). Diatom observations and counting were carried out at high magnification using an AURIGA field emission scanning electron microscope (SEM) and a LEO 1450 SEM (Carl Zeiss Microscopy GmbH., Jena, Germany).

A total of 288 specimens ( 3 subsamples from 4 replicates of 6 thallus parts collected from juvenile and adult specimens of two kelp species) were prepared and analysed with SEM to estimate diatom biofilm densities. Diatom cells attached to the dehydrated kelp subsamples were counted over a surface area of at least $1 \mathrm{~mm}^{2}$ on each of the specimens. For diatom identification, two or three sections of about $2 \mathrm{~cm}^{2}$ of the analysed thalli were digested with boiling concentrated nitric and sulphuric acids at a ratio of 2:1 following the protocol described by von Stosch [37]. The resulting suspension was repeatedly centrifuged and rinsed with distilled water until an approximately neutral $\mathrm{pH}$ was reached. The cleaned diatom material was used to prepare both permanent slides for light microscopy (LM) observations and specimen stubs for SEM. Pleurax [38] was used to mount coverslips on glass slides. A Zeiss AX10 LM equipped with an Axiocam ERc 5s digital camera (Carl Zeiss Microscopy GmbH., Jena, Germany) was used for LM observations supplementing the SEM analysis. The slides and specimen stubs are stored at the Department of Biodiversity and Conservation Biology, UWC. All diatom frustules were identified to at least genus level, following the available literature [7,32,33,39-41].

\subsection{Statistical Analysis}

Statistical analyses of diatom abundance data were performed using the open-source statistical software $\mathrm{R}$ version 3.5.3 [42]. The vegan package version 2.5.5 [43] and the mvabund package version 
3.13.1 [44,45] were used for multivariate analysis of diatom assemblages. Multivariate statistical analysis refers to the mathematical tools aimed to reduce variation in community composition and taxon densities into visible patterns that can inform about the biotic or abiotic parameters that may structure them [10]. Generic diatom abundance data were used rather than species abundance data to detect the major structural patterns and avoid errors related to possible species misidentification. The latter is common and often unavoidable in studies analysing diatom flora from very poorly documented regions and habitats, such as the South African kelp forest.

Diatom abundance data were transformed by applying either proportion normalisation or logarithmic standardisation. Proportion normalisation entailed dividing the count for each taxon in a sample (cells $\mathrm{mm}^{-2}$ ) by the total number of all the taxa counts in that sample or total cells $\mathrm{mm}^{-2}$ (also known as Total Sum Normalisation). This form of normalisation was used to calculate and plot the relative abundance of different epiphytic diatom genera on each analysed kelp subsample. In addition, logarithmic standardisation, which applied the function $\log _{2} x+1$, for $x>0$, where $x$ is the number of cells in $1 \mathrm{~mm}^{2}$, was used for multivariate statistical analyses. Both transformation methods down-weighted the influence of the most abundant taxa on the multivariate analysis [46].

Prior to performing permutational multivariate analysis of variance (PERMANOVA) using the vegan function 'adonis2', the vegan function 'betadisper' was used to check the multivariate homogeneity of groups' dispersion. Subsequently, the function 'permutest' was run to implement a permutation-based test of multivariate homogeneity of group dispersions (variances) on the results of 'betadisper'. Unconstrained ordination plots were produced by principal coordinates analysis (PCoA) to visualise the multivariate homogeneity of group dispersion. Non-metric multidimensional scaling (nMDS) was conducted using the vegan 'metaMDS' function and the Bray-Curtis similarity index with 9999 permutations in order to visualise relationships between the samples based on distance matrices. The 'manyglm' function of the mvabund package version 3.13.1 [47,48] was applied to develop multiple univariate Generalised Linear Models (GLMs) to determine which diatom taxa were responsible for the main differences observed between diatom assemblages on different parts of the host kelp thalli.

\section{Results}

\subsection{Diatom Abundances}

The SEM analyses revealed that epiphytic diatoms were unevenly distributed across the various thallus parts and subsamples (Figures 3 and 4). In general, diatoms tended to cluster within what appeared to be damaged macroalgal tissues, microcracks, and microfolds (Figure $3 \mathrm{~A}-\mathrm{C}$ and Figure $4 \mathrm{~A}-\mathrm{C})$. 

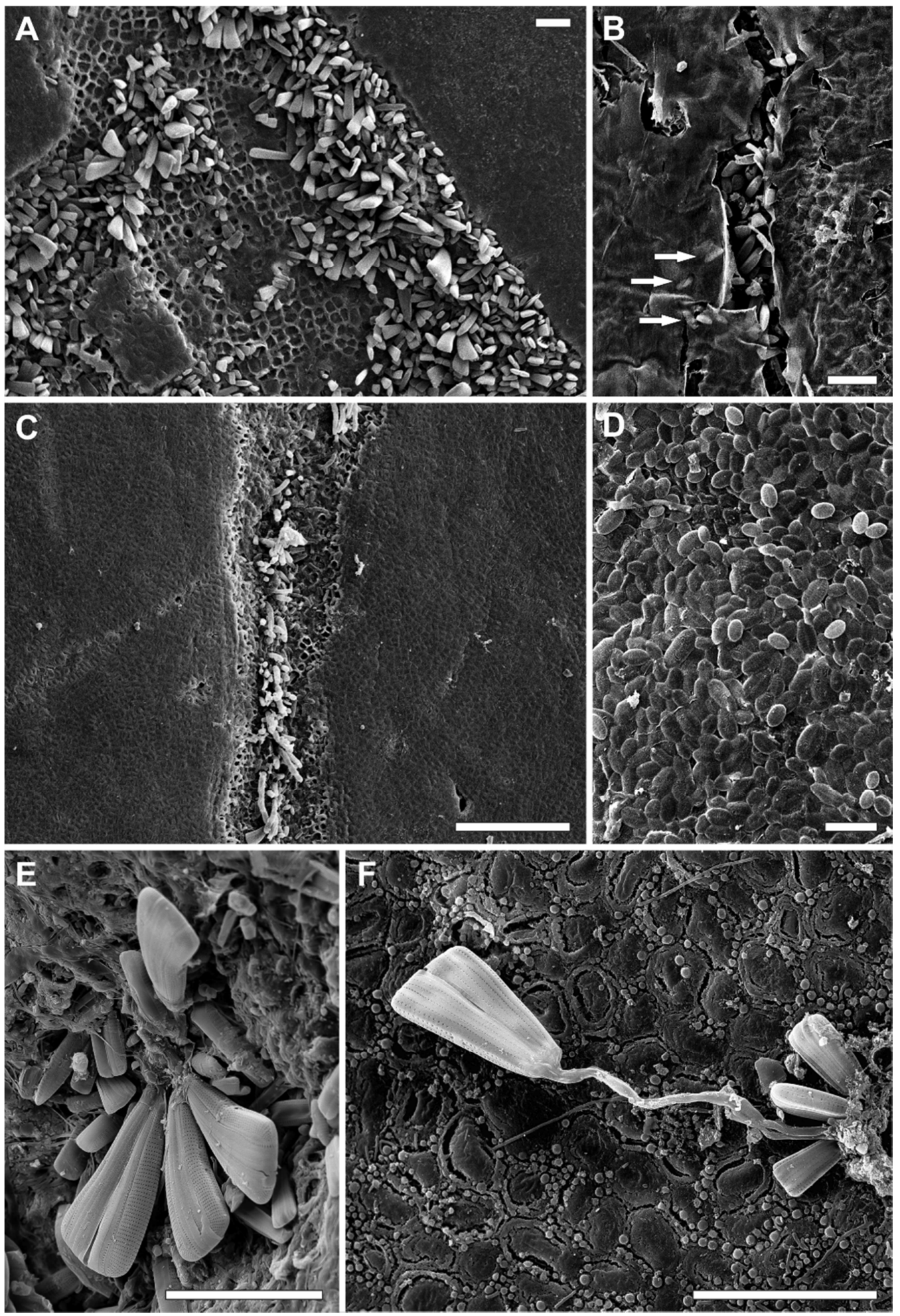

Figure 3. Scanning electron microscope (SEM) micrographs showing diatom assemblages on South African kelps. (A-C,E) Diatoms colonising cracks in the surface layer. (B) Diatoms underneath the flaking kelp tissue. Arrows indicate diatoms completely covered by the thin sloughing layer. (D) Cocconeis costata colonising the smooth surface of the kelp thallus. (E) Rhoicosphenia flexa, Gomphoseptatum pseudoseptatum, and Navicula sp. (F) Gomphoseptatum pseudoseptatum. Scale bars: A, B and D-F $=20 \mu \mathrm{m} ; \mathrm{C}=100 \mu \mathrm{m}$. 

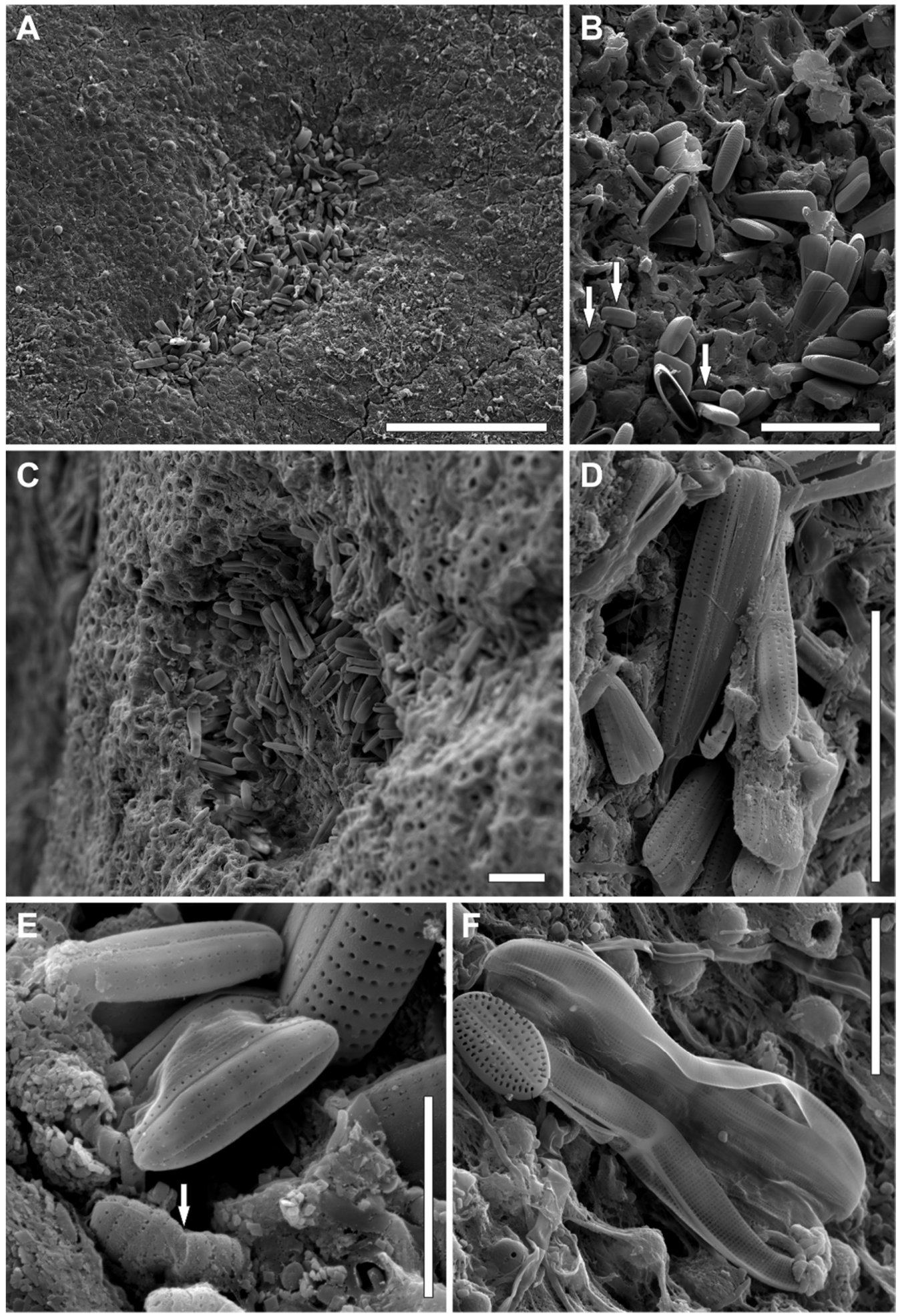

Figure 4. SEM micrographs showing diatom assemblages on South African kelps. (A-E) Diatoms colonising cavities in the surface layer. (B) Rhoicosphenia genuflexa, Gomphoseptatum pseudoseptatum, and Nagumoea sp. (arrows). (C) Assemblage dominated by Navicula spp. (D) Gomphoseptatum pseudoseptatum. (E) Nagumoea sp. and apical part of a cell of Gomphoseptatum pseudoseptatum (arrow) immersed in the kelp tissue. (F) Craspedostauros australis. Scale bars: A $=100 \mu \mathrm{m}$; B-D $=20 \mu \mathrm{m}$; $\mathrm{E}=5 \mu \mathrm{m} ; \mathrm{F}=10 \mu \mathrm{m}$. 
Mean absolute diatom abundances recorded on Ecklonia maxima ranged from 4 (standard deviation (SD) 2) cells $\mathrm{mm}^{-2}$ (lower blade) to 404 (SD 647) cells $\mathrm{mm}^{-2}$ (upper blade) on adult specimens, and from 43 (SD 66) cells $\mathrm{mm}^{-2}$ (primary blade) to 248 (SD 395) cells $\mathrm{mm}^{-2}$ (lower blade) on juvenile specimens (Table 1). Similarly, on Laminaria pallida, the mean diatom density ranged from 7 (SD 5) cells $\mathrm{mm}^{-2}$ (primary blade) to 120 (SD 130) cells $\mathrm{mm}^{-2}$ (lower stipe) on adults and from 38 (SD 77) cells $\mathrm{mm}^{-2}$ (primary blade) to 187 (SD 161) cells $\mathrm{mm}^{-2}$ (holdfast) on juvenile specimens (Table 1). On 12 subsamples, including thallus pieces of seven adult (one primary blade, three lower blade, and three upper stipe specimens) and four juvenile (primary blade) specimens of L. pallida and one adult specimen of E. maxima (primary blade), diatoms were not found. Those subsamples were excluded from further analyses. In general, the highest diatom abundances were recorded on the upper blade (197 cells $\mathrm{mm}^{-2}$; SD 376) and lower stipe (126 cells $\mathrm{mm}^{-2}$; SD 217), and the lowest on the primary blade (27 cells $\mathrm{mm}^{-2}$; SD 52) and upper stipe (52 cells $\mathrm{mm}^{-2}$; SD 138). Diatom abundances were higher on juvenile (114 cells $\mathrm{mm}^{-2}$; SD 218) than on adult specimens ( 80 cells $\mathrm{mm}^{-2}$; SD 221) and on $E$.

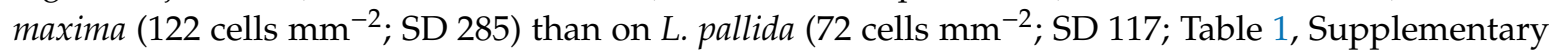
Figures S1-S4).

Table 1. Mean diatom abundance (cells $\mathrm{mm}^{-2}$ ) and standard deviation (SD) calculated for different thallus parts of adult and juvenile specimens of Ecklonia maxima and Laminaria pallida.

\begin{tabular}{|c|c|c|c|c|}
\hline \multicolumn{3}{|c|}{ Substatum } & \multirow{2}{*}{$\frac{\text { Mean Diatom Abundance }}{39}$} & \multirow{2}{*}{$\begin{array}{c}\text { SD } \\
51\end{array}$} \\
\hline \multirow{6}{*}{$\begin{array}{l}\text { Ecklonia } \\
\text { maxima }\end{array}$} & \multirow{6}{*}{ Adult } & Holdfast & & \\
\hline & & Lower stipe & 139 & 105 \\
\hline & & Upper stipe & 19 & 14 \\
\hline & & Primary blade & 21 & 15 \\
\hline & & Lower blade & 4 & 2 \\
\hline & & Upper blade & 404 & 647 \\
\hline \multirow{6}{*}{$\begin{array}{l}\text { Ecklonia } \\
\text { maxima }\end{array}$} & \multirow{6}{*}{ Juvenile } & Holdfast & 104 & 116 \\
\hline & & Lower stipe & 198 & 400 \\
\hline & & Upper Stipe & 139 & 258 \\
\hline & & Primary blade & 43 & 66 \\
\hline & & Lower blade & 248 & 395 \\
\hline & & Upper Blade & 120 & 263 \\
\hline \multirow{6}{*}{$\begin{array}{l}\text { Laminaria } \\
\text { pallida }\end{array}$} & \multirow{6}{*}{ Adult } & Holdfast & 73 & 116 \\
\hline & & Lower stipe & 120 & 130 \\
\hline & & Upper stipe & 9 & 15 \\
\hline & & Primary blade & 7 & 5 \\
\hline & & Lower blade & 24 & 69 \\
\hline & & Upper blade & 110 & 118 \\
\hline \multirow{6}{*}{$\begin{array}{l}\text { Laminaria } \\
\text { pallida }\end{array}$} & \multirow{6}{*}{ Juvenile } & Holdfast & 187 & 161 \\
\hline & & Lower stipe & 49 & 32 \\
\hline & & Upper stipe & 41 & 54 \\
\hline & & Primary blade & 38 & 77 \\
\hline & & Lower blade & 54 & 110 \\
\hline & & Upper blade & 155 & 201 \\
\hline \multicolumn{3}{|c|}{ Holdfast } & 100 & 127 \\
\hline \multicolumn{3}{|c|}{ Lower stipe } & 126 & 217 \\
\hline \multicolumn{3}{|c|}{ Upper stipe } & 52 & 138 \\
\hline \multicolumn{3}{|c|}{ Primary blade } & 27 & 52 \\
\hline \multicolumn{3}{|c|}{ Lower blade } & 82 & 224 \\
\hline \multicolumn{3}{|c|}{ Upper blade } & 197 & 376 \\
\hline \multicolumn{3}{|c|}{ Adult } & 80 & 221 \\
\hline \multicolumn{3}{|c|}{ Juvenile } & 114 & 218 \\
\hline \multicolumn{3}{|c|}{ Ecklonia maxima } & 122 & 285 \\
\hline \multicolumn{3}{|c|}{ Laminaria pallida } & 72 & 117 \\
\hline
\end{tabular}




\subsection{Diatom Community Composition}

Forty-eight diatom taxa (28 genera) were identified during the examination of the clean diatom material (Figures 3 and 4, Supplementary Table S1). Most of these taxa were rarely observed during the diatom counts, and six genera, Actinoptychus Ehrenberg, Campyloneis Grunow, Delphineis G.W.Andrews, Halamphora (Cleve) Mereschkowsky, Mastogloia Thwaites ex W.Smith, and Pleurosigma W.Smith, were observed during the additional observations of the cleaned material only. The genera Gomphoseptatum Medlin, Nagumoea Witkowski and Kociolek, Cocconeis Ehrenberg, and Navicula Bory were the most frequently occurring, being present in $84 \%, 65 \%, 62.5 \%$, and $45 \%$ of the analysed subsamples, respectively (Figures 3-8). Among these, Cocconeis and Gomphoseptatum were the most abundant, contributing $50 \%$ and $27 \%$ of the total diatom cells counted collectively across all subsamples, respectively (Figures 3 and 4A,B,D,E). These two genera were sometimes observed growing in densely packed clusters, covering a significant portion of the analysed kelp surface (Figure 3A,D). Eight genera, including the above-mentioned Cocconeis, Gomphoseptatum, Nagumoea, and Navicula, as well as Amphora Ehrenberg ex. Kützing, Craspedostauros E.J. Cox, Grammatophora Ehrenberg, and Rhoicosphenia Grunow, contributed $100 \%$ of the total diatom number in at least one subsample (Figures 3-8). On average, Cocconeis dominated in holdfast samples of L. pallida, holdfast and upper blade samples of adult E. maxima, and almost all thallus parts (except for primary blade) of juvenile E. maxima, with Gomphoseptatum dominating on the remaining thallus parts (Supplementary Figures S1-S4). Typically planktonic forms, such as Cyclotella (F.T. Kützing) A. de Brébisson, Cylindrotheca Rabenhorst, and Skeletonema Greville, were rarely observed (Figures 5-8).

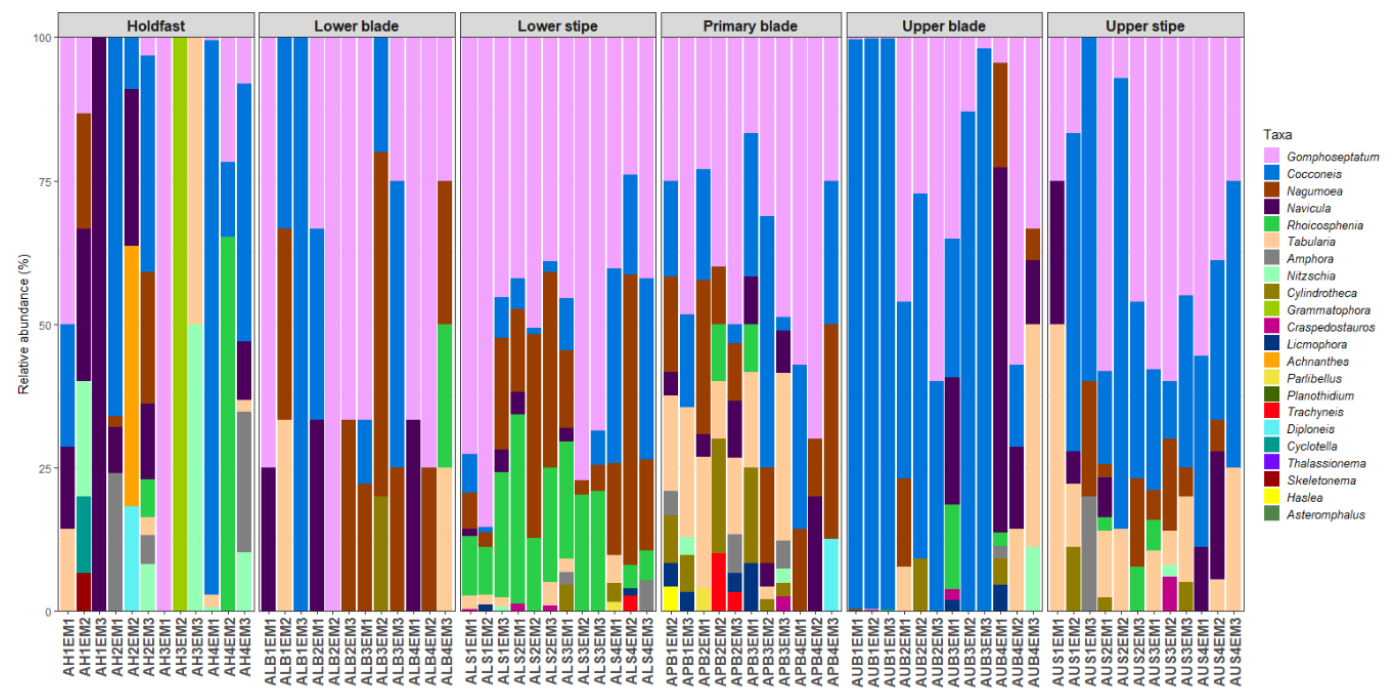

Figure 5. Relative abundance of diatom genera on different parts of adult specimens of Ecklonia maxima. 


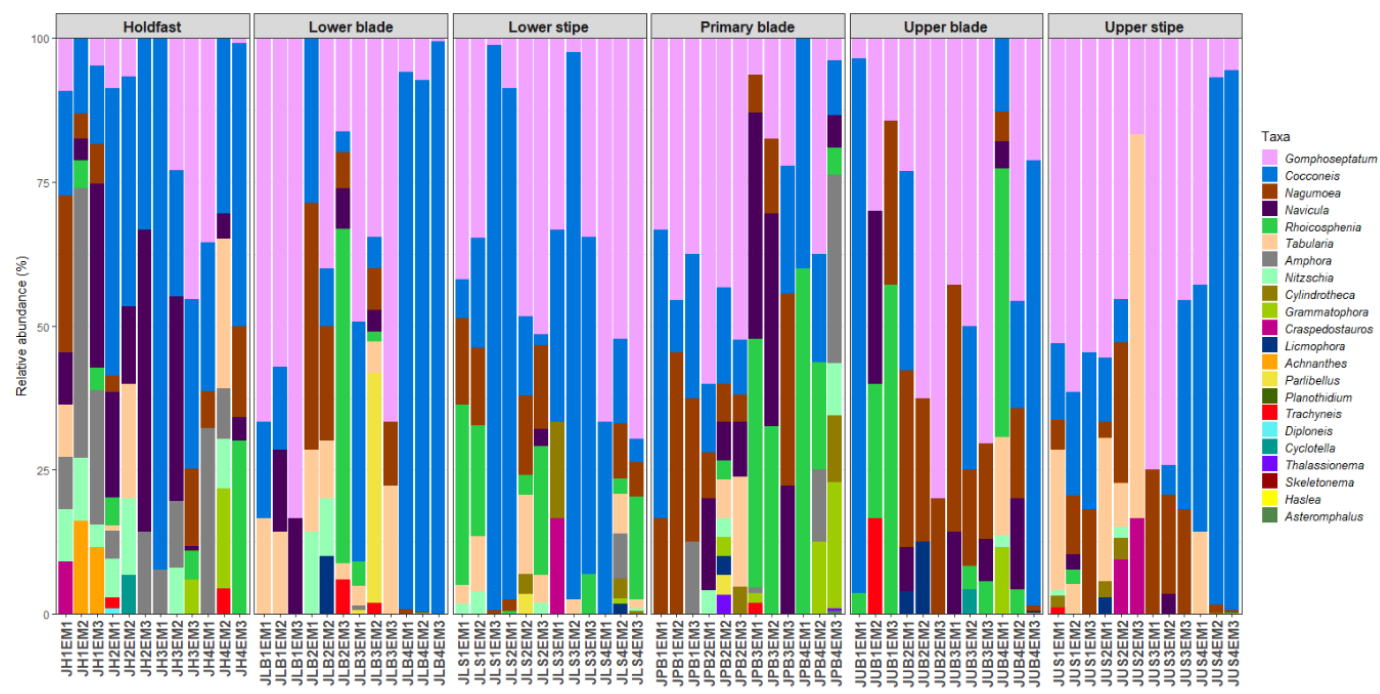

Figure 6. Relative abundance of diatom genera on different parts of juvenile specimens of Ecklonia maxima.

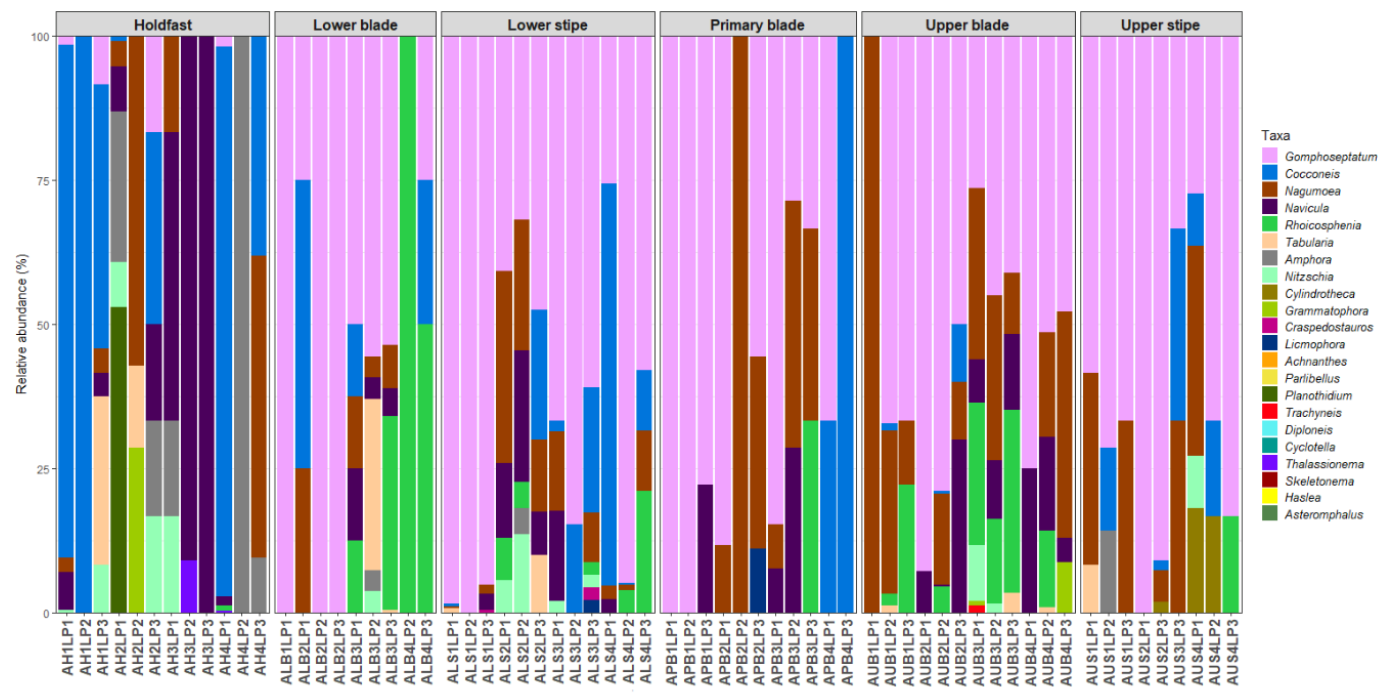

Figure 7. Relative abundance of diatom genera on different parts of adult specimens of Laminaria pallida.

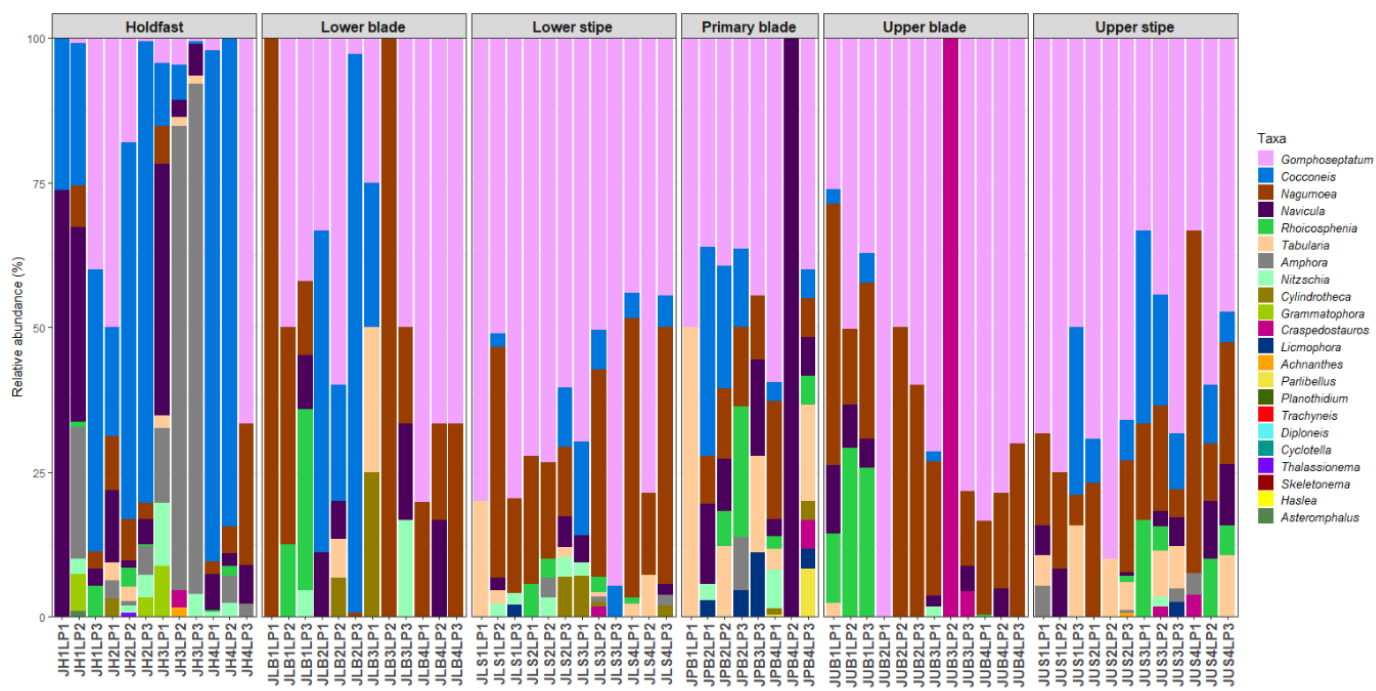

Figure 8. Relative abundance of diatom genera on different parts of juvenile specimens Laminaria pallida. 


\subsection{Host Kelp Species, Age, and Thallus Part Effects on Diatom Communities}

The analysis of multivariate homogeneity of group dispersion testing the influence of the host species indicated no significant differences between the two sample groups ( $p=0.24$; Figure 9A. However, significant differences were found between the kelp age groups ( $p=0.0033$; Figure $9 \mathrm{~B})$ and different thallus parts tested ( $p=0.0001$; Figure 9C). Although the correlation between the observed dissimilarity and the ordination distances was high (non-metric fit, $R^{2}=0.96$ ), the high stress value (0.20) indicated a significant distortion of the two-dimensional (2D) arrangement of the sample points displayed by the nMDS plot (Figure 10A,B).
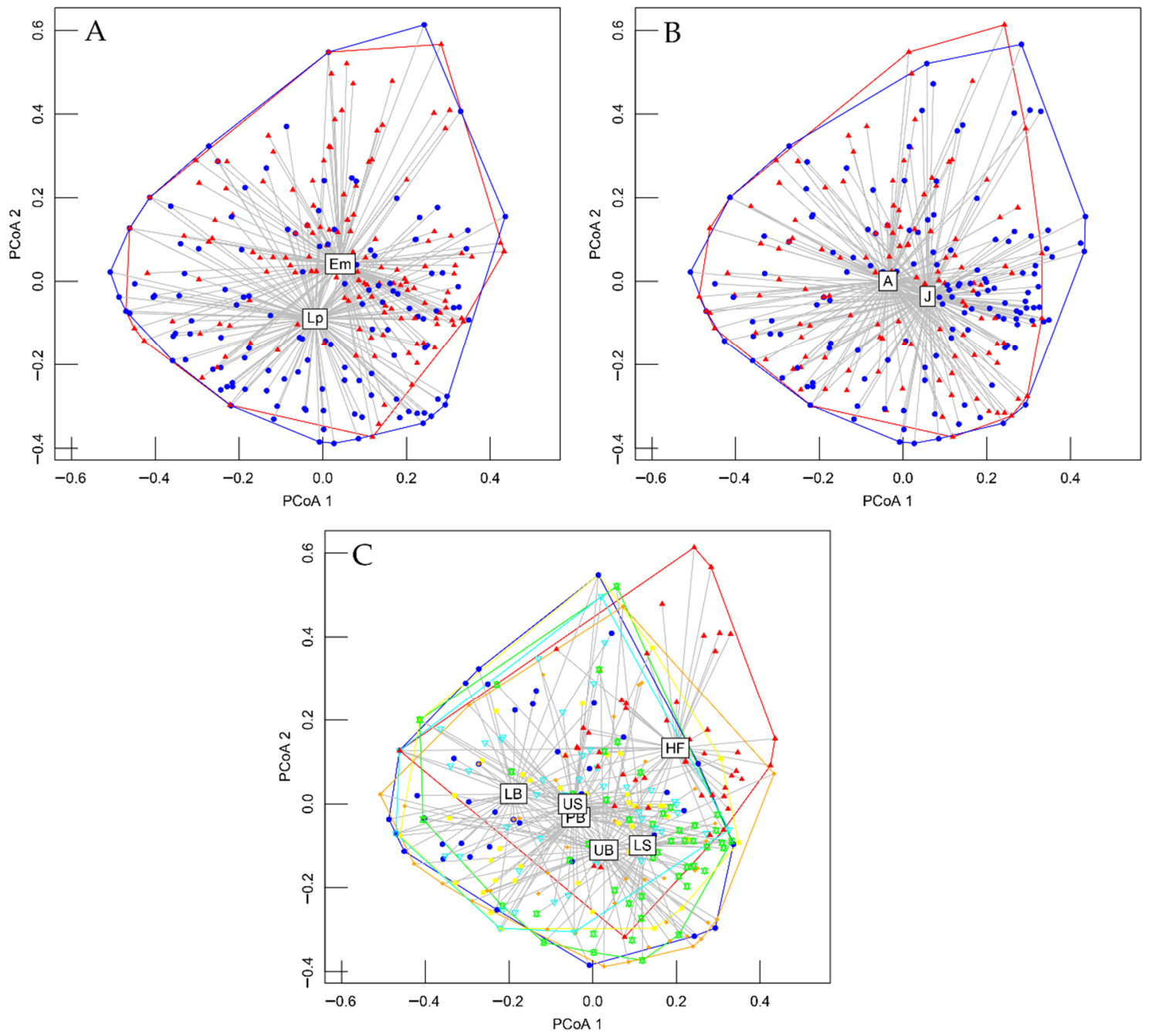

Figure 9. Principal coordinates analysis ( $\mathrm{PCoA}$ ) plots visualising the multivariate homogeneity of group dispersion based on the epiphytic diatom abundances data grouped by host kelp (A) species, Ecklonia maxima (Em, red), Laminaria pallida (Lp, blue), (B) age, A = Adult (red), J = Juvenile (blue), and (C) thallus part, HF = Holdfast (red), LS = Lower stipe (green), US = Upper stipe (cyan), PB = Primary blade (yellow), LB = Lower blade (blue), UB = Upper blade (orange). 


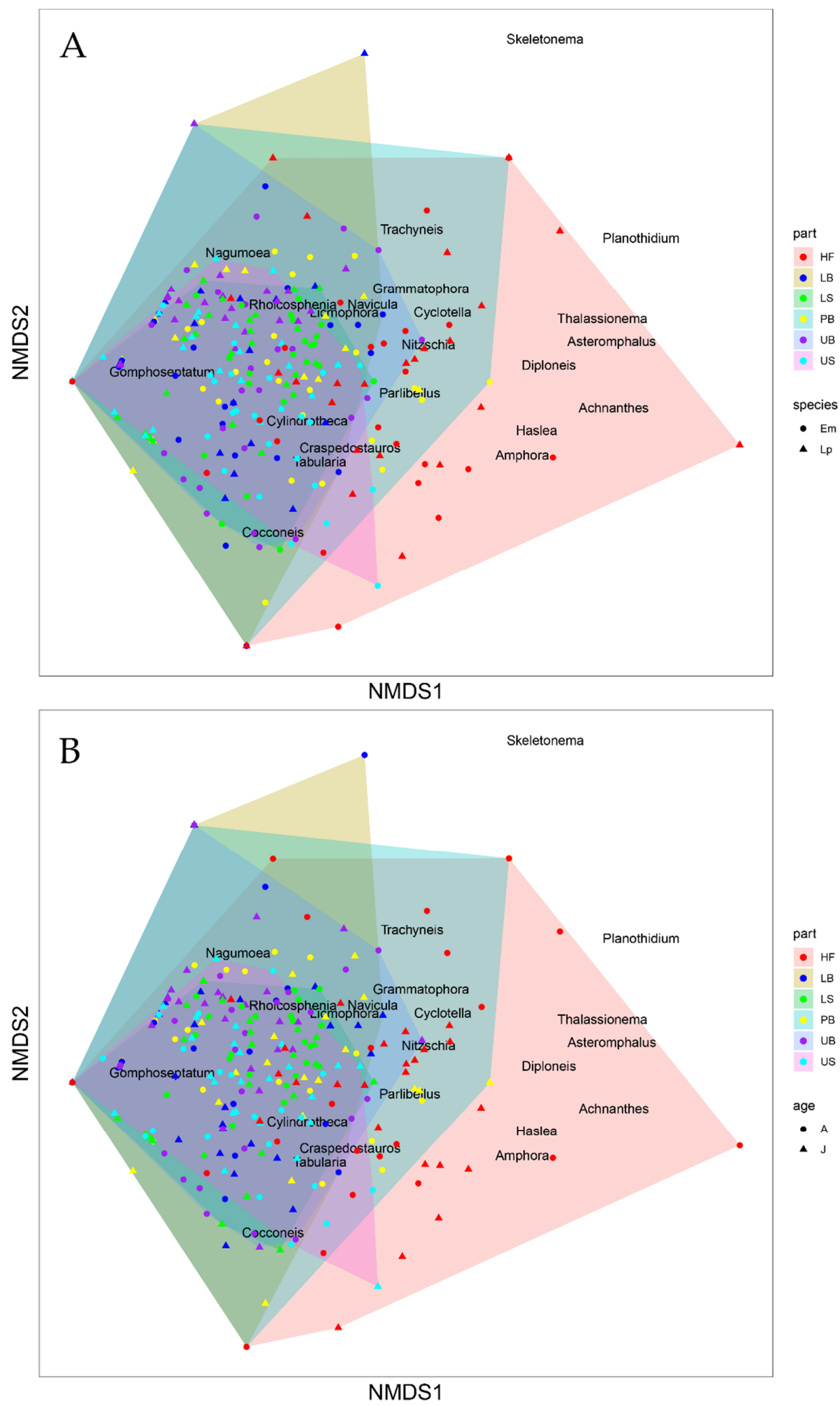

Figure 10. Non-metric multidimensional scaling (nMDS) graphs showing distances between the diatom samples collected from (A) different host species and thallus parts and (B) different thallus parts of juvenile and adult kelps as their overall dissimilarity (two-dimensional (2D) Stress $=\sim 0.20$ ). $\mathrm{HF}=$ Holdfast, $\mathrm{LB}=$ Lower blade, $\mathrm{LS}=$ Lower stipe, $\mathrm{PB}=$ Primary blade, UB = Upper blade, US = Upper stipe; $\mathrm{Em}=$ Ecklonia maxima, $\mathrm{Lp}=$ Laminaria pallida $; \mathrm{A}=$ Adult $\mathrm{J}=$ Juvenile. 
PERMANOVA partitioning indicated that the epiphytic diatom community composition and abundances on the South African kelps studied were significantly influenced by the three tested factors, i.e., the thallus part (Sum of Squares (SS) $=8.752, R^{2}=0.147, p=0.0001$; Table 2), as well as the host species $\left(S S=1.701, R^{2}=0.029, p=0.0001\right.$; Table 2$)$ and age $\left(S S=0.730, R^{2}=0.012, p=0.0005\right.$; Table 2). The effects of the interactions between the factors, including the interaction between the host species and thallus part ( $S S=1.377, R^{2}=0.023, p=0.0163$; Table 2), as well as the interaction between the host age and thallus part $\left(S S=2.034, R^{2}=0.034, p=0.0002\right.$; Table 2), but not between the host species and age ( $S S=0.196, R^{2}=0.003, p=0.3248$; Table 2), were significant. The effect of the three-way interaction between all three tested factors on the diatom communities was also significant $\left(S S=1.838, R^{2}=0.031\right.$, $p=0.0003$; Table 2). Nevertheless, the residual variance was high $\left(S S=42.989, R^{2}=0.721\right.$; Table 2).

Table 2. Results of three-way crossed permutational multivariate analysis of variance (PERMANOVA) testing for the effects of kelp species, kelp age, and thallus part on the composition and abundance of epiphytic diatoms growing on Ecklonia maxima and Laminaria pallida.

\begin{tabular}{cccccc}
\hline Factor & $d f$ & $S S$ & $\boldsymbol{R}^{\mathbf{2}}$ & $\boldsymbol{F}$ & $\boldsymbol{p}^{*}$ \\
\hline Species & 1 & 1.701 & 0.029 & 9.972 & $\mathbf{0 . 0 0 0 1}$ \\
Age & 1 & 0.730 & 0.012 & 4.278 & $\mathbf{0 . 0 0 0 5}$ \\
Part & 5 & 8.752 & 0.147 & 10.261 & $\mathbf{0 . 0 0 0 1}$ \\
Species $\times$ Age & 1 & 0.196 & 0.003 & 1.146 & 0.3248 \\
Species $\times$ Part & 5 & 1.377 & 0.023 & 1.615 & $\mathbf{0 . 0 1 6 3}$ \\
Age $\times$ Part & 5 & 2.034 & 0.034 & 2.384 & $\mathbf{0 . 0 0 0 2}$ \\
Species $\times$ Age $\times$ Part & 5 & 1.838 & 0.031 & 2.155 & $\mathbf{0 . 0 0 0 3}$ \\
Residual & 252 & 42.989 & 0.721 & & \\
Total & 275 & 59.617 & 1.000 & &
\end{tabular}

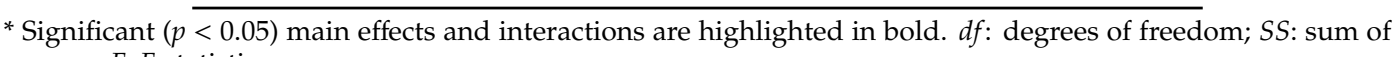
squares; F: F-statistic.

The 'manyglm' model confirmed that the influences of all three tested factors, i.e., the host species $(p=0.002)$, the host age $(p=0.005)$, and the thallus part $(p=0.001)$ on epiphytic diatom communities were significant. Similarly, the effects of the two-way interactions between the host species and thallus part $(p=0.001)$ and the host age and thallus part $(p=0.001)$, as well as the three-way interaction between the host species, age, and thallus part $(p=0.001)$, were also significant. Univariate 'genus by genus' results of the 'manyglm' model revealed that the abundances of 11 diatom genera, including Ampohora $(p=0.001)$, Cocconeis $(p=0.001)$, Craspedostauros $(p=0.004)$, Cylindrotheca $(p=0.002)$, Gomphoseptatum $(p=0.001)$, Grammatophora $(p=0.026)$, Licmophora $(p=0.011)$, Nagumoea $(p=0.001)$, Navicula $(p=0.001)$, Nitzschia $(p=0.017)$, and Rhoicosphenia $(p=0.001)$, were significantly influenced by the thallus part (Figure 11). Additionally, the abundances of Cocconeis $(p=0.010)$ and Amphora $(p=0.047)$ were also significantly affected by host species and age effects, respectively. There was no significant influence of the two-way interaction between host species and host age. However, the abundances of Cocconeis $(p=0.001)$ and Nagumoea $(p=0.011)$ were significantly influenced by the interaction between host species and thallus part. Similarly, the interaction between host age and thallus part significantly affected the abundances of Cocconeis $(p=0.001)$, Gomphoseptatum $(p=0.003)$, and Navicula $(p=0.008)$. Finally, the abundances of Cocconeis $(p=0.037)$, Gomphoseptatum $(p=0.041)$, and Tabularia $(p=0.001)$ were significantly influenced by the three-way interaction between host species, age, and thallus part effects. 


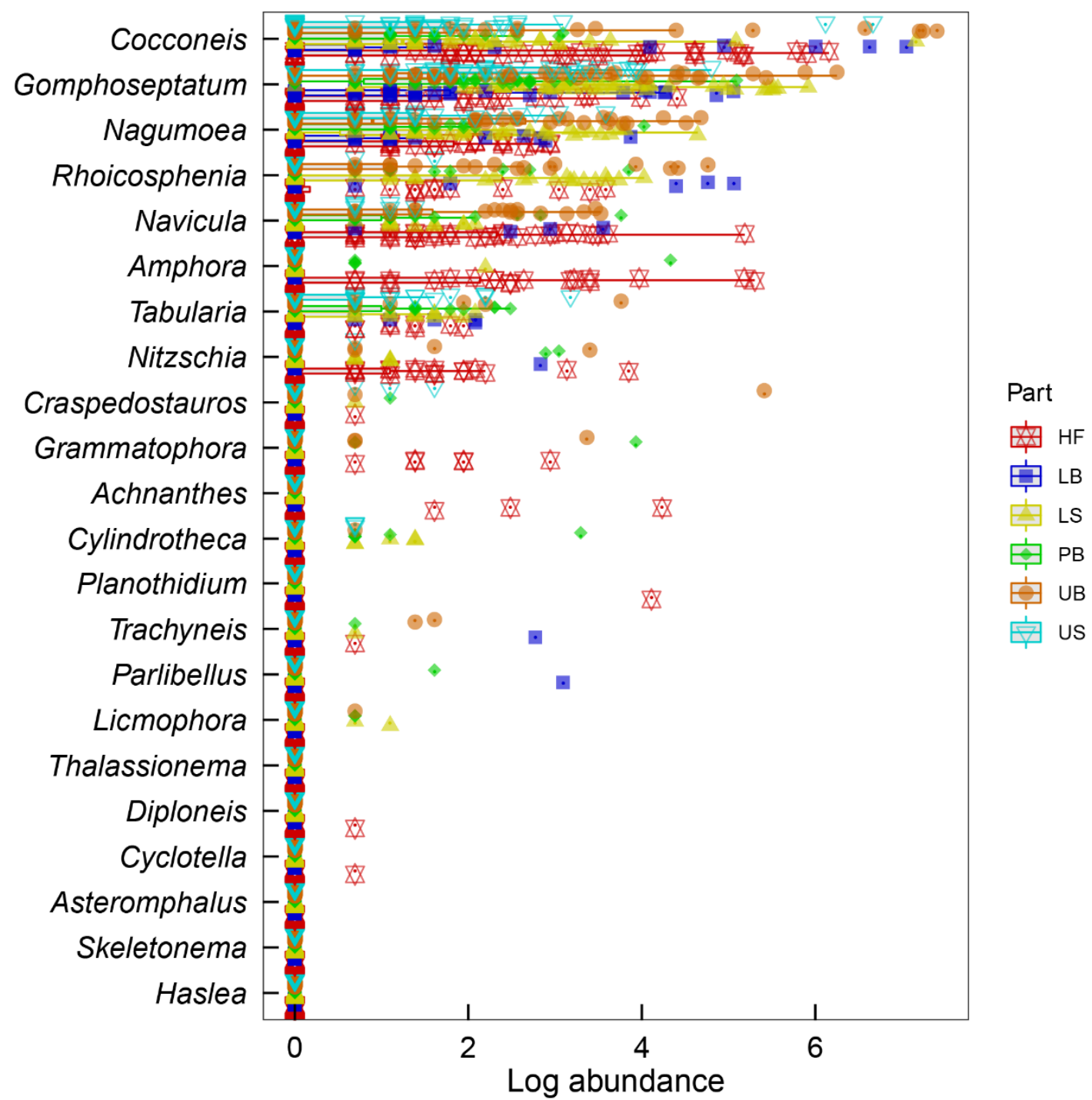

Figure 11. Univariate Generalised Linear Models (GLMs) fitted individually to each diatom genus based on different parts of kelp thalli, showing most influential diatom genera. Small dots beneath some data points denote outliers. HF = Holdfast, LB = Lower blade, LS = Lower stipe, $\mathrm{PB}=$ Primary blade, $\mathrm{UB}=$ Upper blade, US = Upper stipe.

\section{Discussion}

The current study indicated that all investigated biotic factors, i.e., the host species, age, and different part of the thallus, significantly affected both the abundances and taxonomic composition of the kelp-associated diatom communities. Among these, the influences of the kelp thallus part and the host age were the most and least pronounced, respectively. The high residual variance $(72 \%)$ indicated that other factors likely contributed to the diatom community structuring. However, since all kelp samples were collected on the same day from the same sampling spot, abiotic factors related to seasonality and hydrological conditions of the site should be excluded as a possible explanation for the observed patterns. Based on the SEM analysis of the kelp surface, we infer that both grazing and the kelp response to grazer-caused damage and biofouling by epiphytes, as well as specific life strategies employed by kelp-associated diatoms, may be responsible for a large portion of the unexplained variation. As the diatom abundances and distribution patterns were strongly linked to the diatom community composition and different ecological niches used by dominant diatom species, these two community characteristics will be discussed simultaneously. 
In line with the previous findings [23], the current study indicated that diatom abundances on the two species of South African kelps, ranging from 0 to 404 cells $\mathrm{mm}^{-2}$, were relatively low, as compared with other studies on the densities of macroalgae-associated diatom biofilm $[6,8,9,12,14,49,50]$. Nevertheless, significant differences in diatom abundances were detected between the morphologically and functionally different parts of the kelp thallus, with the primary blades [23] hosting the lowest and the upper blades the highest number of diatoms. Differences in mean diatom abundances were observed between different host species and age, with Ecklonia maxima and juvenile specimens hosting more diatoms than Laminaria pallida and adult kelp individuals. Several studies have reported similarly low diatom abundances on various kelp species $[6,8,51,52]$, which may be related to both the specific morphology and physiology of this group of macroalgae. It has been suggested that macro- and micro-topographically uniform smooth blades of large kelps may not be a preferred attachment surface for many diatom taxa $[8,13,49]$, while epithelial cell sloughing that is most likely common in long-lived kelps $[18,19,21]$ would effectively limit the number of diatoms developing on the thallus. Moreover, production of secondary metabolites is used by various kelp species to deter herbivores [53-55]. However, the bioactive compounds excreted by macroalgae may affect not only grazers but also the microalgal biofoulers-both directly and indirectly.

Almost all kelp samples (excluding those that did not contain any diatoms) were dominated by firmly attaching adnate Cocconeis spp. and small-celled forms from the genera Gomphoseptatum, Navicula, Nagumoea, and Rhoicosphenia, which utilise different attachment techniques to colonise the kelp surface. In general, diatom distribution on the kelp thallus was highly uneven, and many diatoms (especially the erect forms such as Gomphoseptatum and Rhoicosphenia) tended to cluster in natural (i.e., induced by the kelp physiology) and mechanically created (i.e., induced by physical abrasion or grazing) cavities. Thus, thallus parts with a higher number of such microniches (e.g., extensively abraded and grazed upper blades of L. pallida) tended to host more diatom cells. On the other hand, adnate Cocconeis was sometimes present in high abundances on smooth homogenous surfaces. The latter group of diatoms was, therefore, responsible for higher diatom abundances recorded from thalli showing a lower degree of the surface layer damage but possibly characterised by reduced surface layer sloughing (e.g., holdfasts).

Although the influence of secondary metabolites produced by kelps on epiphytic microalgae is not yet well understood, diatom distribution, being strongly linked to grazing activity of herbivores, will be indirectly affected by anti-grazing compounds excreted by the host macroalga as well as the taxonomic composition of the local grazer communities. For example, gastropods that represent one of the most common groups of macroalgal and epiphytic diatom grazers [56-58] feed unselectively on diatoms and kelp tissue using radulae-structures, with which food particles are scraped off the kelp surface $[59,60]$. The extent and distribution of the kelp tissue damage caused by these grazers depends on the gastropod species and type of radulae they possess [59], as not all gastropods will be able to feed on certain kelp species or thallus parts. Holdfast and stipe are usually significantly tougher than meristem and mid-region (primary and lower blade), whereas lamina frill (upper blade) is often less leathery and easier to graze than all other thallus parts [61]. On the other hand, concentrations of grazer-deterring compounds vary between different thallus parts and are generally higher in reproductive units and physiologically essential regions (e.g., intercalary meristem and primary blade) than in vegetative peripheral zones (e.g., upper blade) [54,61]. Thus, adnate diatom taxa (e.g., Cocconeis), which are more susceptible to grazing by non-selective herbivores but can attach to and develop on smooth homogenous surfaces, may gain a competitive advantage in poorly grazed thallus parts, whereas tissue-boring forms (Gomphoseptatum, Rhoicosphenia) may prefer heavily grazed, damaged areas that provide them access to the underlying more porous tissue layer.

The SEM observations showed that many diatoms were almost entirely immersed in the thallus tissue. In some instances, diatom frustules were visible under the sloughing surface layer of the kelp (Figure 3B). As cross-sections of the thallus were not analysed, it remains unknown whether tissue-boring forms such as Gomphoseptatum pseudoseptatum (Giffen) Witkowski, Lange-Bertalot \& 
Metzeltin and Rhoicosphenia genuflexa (Kützing) Medlin observed during this study are adapted to a fully endophytic lifestyle. Moreover, it is not clear whether these diatoms caused or significantly contributed to the further degradation of the thallus. Klotchkova et al. [62] showed that tissue damage in two species of the red algae Neoabbottiella Perestenko was linked to the presence of a diatom identified as Pseudogomphonema sp., that developed both in the medullar layer and cortex of the host macroalgae as well as on its surface. Both endo- and epi-phytic forms were normally pigmented and most likely photosynthetically active, despite the very low light intensities transmitted into the deeper layers of the thallus, leading the authors to propose a mixotrophic mode of nutrition for this diatom taxon [62]. We speculate that tissue-boring taxa observed in the current study that share the "gomphonemoid" shape and growth form with the endobiotic Pseudogomphonema sp. may utilise the same mechanisms to colonise their kelp hosts. It is possible that the clavate elongated shape of the diatom frustules represents functional morphology that facilitates spacing of the host cells and thus colonisation of the deeper tissue layers. As previously observed by Klotchkova et al. [62], the tissue-boring diatoms, despite causing visible tissue damage and often inducing the so-called warping of the thallus, do not seem to change the host physiology or affect its growth rates, and their ecological role is not well understood. It has been suggested that growth of apochlorotic and mixotrophic macroalgae-associated endophytic diatoms is enhanced by significant amounts of extracellular carbon released from the damaged and decaying thallus [63-65]. Interestingly, Armstrong et al. [66] observed that, on the damaged macroalgal surface, bacterial numbers were lower when endophytic diatoms were present, suggesting that the latter might be more efficient competitors for released dissolved organic carbon. If so, epi- and endo-phytic diatoms may indirectly protect the host from potentially more harmful bacterial pathogens and contribute to the macroalgal tissue sealing through the development of the superficial warp.

It should be noted that none of the three analysed factors acted entirely independently, with most of their interaction effects also being significant. For example, since the degree of colonisation is often proportional to the time of exposure to marine environment [17], older thallus parts that show no meristematic activity (e.g., upper blades) would host a higher number of epibionts. Moreover, the external (e.g., grazing) and other host-related factors (e.g., regular external layer sloughing) would most likely play an important role. Generally, low diatom abundances and community complexity indicate that epiphytes on kelps are restricted due to continuous disturbance and disruption of the biofilm at the early stages of its development. Thus, new communities established rapidly by a low number of individuals belonging to various pioneering taxa as a result of stochastic processes may differ substantially from the pre-existing communities dislocated by surface sloughing or destroyed by grazers [67]. This phenomenon would further confound or mask the effects of the host species, age, and thallus part, and may explain the relatively high variability in the present dataset.

\section{Conclusions}

Diatom communities associated with Ecklonia maxima and Laminaria pallida are significantly affected by the thallus part, species, and age of their host. Other factors, such as grazing as well as chemical (active compound production) and mechanical (cell sloughing) defence strategies against herbivores and biofouling employed by the kelps, may also, directly and indirectly, affect the epiphytic diatoms. Such influences may, in turn, depend on the kelp species and age and the thallus part, further complicating the patterns of diatom colonisation.

The surfaces of E. maxima and L. pallida are dominated by strongly adhering adnate and erect diatoms showing highly uneven distributions across the host thalli. Naturally occurring cavities and damaged tissue are diatom abundance hot-spots and are colonised by potentially endophytic tissue-boring diatom forms that, however, do not seem to affect the overall fitness of the host. Further studies are required to shed more light on the physiology and ecological role of kelp-associated diatoms and their influence on the host macroalgae. 
Supplementary Materials: The following are available online at http://www.mdpi.com/1424-2818/12/10/385/s1: Table S1: List of diatom taxa recorded in kelp samples. Figure S1: Mean diatom abundances ( \pm Standard Error (SE)) on different thallus parts of adult Laminaria pallida, Figure S2: Mean diatom abundances $( \pm \mathrm{SE})$ on different thallus parts of juvenile Laminaria pallida, Figure S3: Mean diatom abundances $( \pm$ SE) on different thallus parts of adult Ecklonia maxima, Figure S4: Mean diatom abundances $( \pm \mathrm{SE})$ on different thallus parts of juvenile Eckolnia maxima.

Author Contributions: Conceptualization, N.A.S.M., R.M., and A.J.S.; methodology, N.A.S.M., R.M., and A.J.S.; software, N.A.S.M.; validation, N.A.S.M.; formal analysis, N.A.S.M. and A.J.S.; investigation, N.A.S.M. and R.M.; resources, A.J.S. and R.M.; data curation, N.A.S.M.; writing-original draft preparation, N.A.S.M. and R.M.; writing-review and editing, N.A.S.M., R.M., and A.J.S.; visualisation, N.A.S.M. and R.M.; supervision, A.J.S. and R.M.; project administration, A.J.S.; funding acquisition, A.J.S. All authors have read and agreed to the published version of the manuscript.

Funding: This research was funded by the National Research Foundation (NRF), grant number 120123.

Acknowledgments: We thank our colleagues from Team Kelp (UWC) for assisting with sample collection. N.A.S.M. thanks the NRF for granting the MSc scholarship.

Conflicts of Interest: The authors declare no conflict of interest. The funders had no role in the design of the study; in the collection, analyses, or interpretation of data; in the writing of the manuscript, or in the decision to publish the results.

\section{References}

1. Krumhansl, K.A.; Okamoto, D.K.; Rassweiler, A.; Novak, M.; Bolton, J.J.; Cavanaugh, K.C.; Connell, S.D.; Johnson, C.R.; Konar, B.; Ling, S.D.; et al. Global patterns of kelp forest change over the past half-century. Proc. Natl. Acad. Sci. USA 2016, 113, 13785-13790. [CrossRef]

2. Arnold, M.; Teagle, H.; Brown, M.P.; Smale, D.A. The structure of biogenic habitat and epibiotic assemblages associated with the global invasive kelp Undaria pinnatifida in comparison to native macroalgae. Biol. Invasions 2016, 18, 661-676. [CrossRef]

3. Leclerc, J.C.; Riera, P.; Lévêque, L.; Davoult, D. Contrasting temporal variation in habitat complexity and species abundance distributions in four kelp forest strata. Hydrobiologia 2016, 777, 1-22. [CrossRef]

4. Booth, W.E. Contribution by diatoms to marine algal host-epiphyte photosynthesis. Bot. Mar. 1987, 30, 129-140. [CrossRef]

5. Snoeijs, P. Distribution of epiphytic diatom species composition, diversity and biomass on different macroalgal hosts along seasonal and salinity gradients in the Baltic Sea. Diatom Res. 1994, 9, 189-211. [CrossRef]

6. Siqueiros-Beltrones, D.A.; Serviere-Zaragoza, E.; Argumedo-Hernandez, U. Epiphytic diatoms of Macrocystis pyrifera (L.) C. Ag. from the Baja California Peninsula, México. Oceánides 2002, 17, 3-39.

7. Al-Handal, A.Y.; Wulff, A. Marine epiphytic diatoms from the shallow sublittoral zone in Potter Cove, King George Island, Antarctica. Bot. Mar. 2008, 51, 411-435. [CrossRef]

8. Totti, C.; Poulin, M.; Romagnoli, T.; Perrone, C.; Pennesi, C.; de Stefano, M. Epiphytic diatom communities on intertidal seaweeds from Iceland. Pol. Biol. 2009, 32, 1681-1691. [CrossRef]

9. Majewska, R.; Kuklinski, P.; Balazy, P.; Yokoya, N.S.; Martins, A.P.; De Stefano, M. A comparison of epiphytic diatom communities on Plocamium cartilagineum (Plocamiales, Florideophyceae) from two Antarctic areas. Polar Biol. 2015, 38, 189-205. [CrossRef]

10. Medlin, L.K.; Juggins, S. Multivariate analyses document host specificity, differences in the diatom metaphyton vs. epiphyton, and seasonality that structure the epiphytic diatom community. Estuar. Coast. Shelf Sci. 2018, 213, 314-330. [CrossRef]

11. Medlin, L.K.; Fryxell, G.A.; Cox, E.R. Successional sequences of microbial colonisation on three species of Rhodophycean macroalgae. Ann. Bot. 1985, 56, 399-413. [CrossRef]

12. Majewska, R.; Gambi, M.C.; Totti, C.M.; De Stefano, M. Epiphytic diatom communities of Terra Nova Bay, Ross Sea, Antarctica: Structural analysis and relations to algal host. Antarct. Sci. 2013, 25, 501-513. [CrossRef]

13. Costa, M.M.D.S.; Pereira, S.M.B.; Da Silva-Cunha, M.D.G.G.; De Arruda, P.C.; Eskinazi-Leça, E. Community structure of epiphytic diatoms on seaweeds in Northeastern Brazil. Bot. Mar. 2016, 59, 231-240. [CrossRef]

14. Majewska, R.; Convey, P.; De Stefano, M. Summer epiphytic diatoms from Terra Nova Bay and Cape Evans (Ross Sea, Antarctica)—A synthesis and final conclusions. PLoS ONE 2016, 11, e0153254. [CrossRef] [PubMed]

15. Costa, M.M.D.S.; Pereira, S.M.B.; De Arruda, P.C.; Leca, E.E. Quantitative variation of epiphytic diatoms in Galaxaura rugosa (Nemaliales: Rhodophyta). Mar. Biodiv. Rec. 2014, 7, 1-7. [CrossRef] 
16. Chung, M.H.; Lee, K.S. Species composition of the epiphytic diatoms on the leaf tissues of three Zostera species distributed on the southern coast of Korea. Algae 2008, 23, 75-81. [CrossRef]

17. Jennings, J.G.; Steinberg, P.D. Phlorotannins versus other factors affecting epiphyte abundance on the kelp Ecklonia radiata. Oecologia 1997, 109, 461-473. [CrossRef]

18. Moss, B.L. The control of epiphytes by Halidrys siliquosa (L.) Lyngb. (Phaeophyta, Cystoseiraceae). Phycologia 1982, 21, 185-191. [CrossRef]

19. Russell, G.; Veltkamp, C.J. Epiphyte survival on skin-shedding macrophytes. Mar. Ecol. Prog. Ser. 1984, 18, 149-153. [CrossRef]

20. Nylund, G.M.; Pavia, H. Chemical versus mechanical inhibition of fouling in the red alga Dilsea carnosa. Mar. Ecol. Prog. Ser. 2005, 299, 111-121. [CrossRef]

21. Halat, L.; Galway, M.E.; Gitto, S.; Garbary, D.J. Epidermal shedding in Ascophyllum nodosum (Phaeophyceae): Seasonality, productivity and relationship to harvesting. Phycologia 2015, 54, 599-608. [CrossRef]

22. Yamamoto, K.; Endo, H.; Yoshikawa, S.; Ohkia, K.; Kamiya, M. Various defense ability of four sargassacean algae against the red algal epiphyte Neosiphonia harveyi in Wakasa Bay, Japan. Aquat. Bot. 2013, 105, 11-17. [CrossRef]

23. Mayombo, N.A.S.; Majewska, R.; Smit, A.J. Diatoms associated with two South African kelp species: Ecklonia maxima and Laminaria pallida. Afr. J. Mar. Sci. 2019, 41, 221-229. [CrossRef]

24. Russell, G. Formation of an ectocarpoid epiflora on blades of Laminaria digitata. Mar. Ecol. Prog. Ser. 1983, 11, 181-187. [CrossRef]

25. Russell, G. Parallel growth patterns in algal epiphytes and Laminaria blades. Mar. Ecol. Prog. Ser. 1983, 13, 149-153. [CrossRef]

26. Amsler, C.D.; Okogbue, I.N.; Landry, D.M.; Amsler, M.O.; McClintock, J.B.; Baker, B.J. Potential chemical defences against diatom fouling in Antarctic macroalgae. Bot. Mar. 2005, 48, 318-322. [CrossRef]

27. Cundell, A.M.; Sleeter, T.D.; Mitchell, R. Microbial Populations Associated with the Surface of the Brown Alga Ascophyllum nodosum. Microb. Ecol. 1977, 4, 81-91. [CrossRef]

28. Walsh, G.; Wepener, V. The influence of land use on water quality and diatom community structures in urban and agriculturally stressed rivers. Water SA 2009, 35, 579-594. [CrossRef]

29. Witon, E.; Witkowski, A. Holocene diatoms (Bacillariophyceae) from Faeroe Islands Fjords, Northern Atlantic Ocean. II. Distribution and taxonomy of marine taxa with special reference to benthic forms. Diatom Res. 2006, 21, 175-215. [CrossRef]

30. Desianti, N.; Potapova, M.; Enache, M.; Belton, T.J.; Velinsky, D.J.; Thomas, R.; Mead, J. Sediment diatoms as environmental indicators in New Jersey coastal lagoons. J. Coast. Res. 2017, 78, 127-140. [CrossRef]

31. Giffen, M.H. Marine littoral diatoms from the Gordon's Bay region of False Bay Cape Province, South Africa. Bot. Mar. 1971, 14, 1-16. [CrossRef]

32. Giffen, M.H. Diatoms of the marine littoral of Steenberg's Cove in St. Helena Bay, Cape Province, South Africa. Bot. Mar. 1973, 16, 32-48. [CrossRef]

33. Giffen, M.H. A further account of the marine littoral diatoms of the Saldanha Bay Lagoon, Cape Province, South Africa. Bot. Mar. 1976, 19, 379-394. [CrossRef]

34. Bolton, J.J. Marine phytogeography of the Benguela Upwelling Region on the west coast of Southern Africa: A temperature dependent approach. Bot. Mar. 1986, 29, 251-256. [CrossRef]

35. Brown, A.C.; Jarman, N. Coastal marine habitats. In Biogeography and Ecology of Southern Africa; Werger, M.J.A., Ed.; Monographiae Biologicae, Springer: Dordrecht, The Netherlands, 1978; Volume 31.

36. Anderson, R.J.; Carrick, P.; Levitt, G.J.; Share, A. Holdfasts of adult kelp Ecklonia maxima provide refuges from grazing for recruitment of juvenile kelps. Mar. Ecol. Prog. Ser. 1997, 159, 265-273. [CrossRef]

37. Hasle, G.R.; Syvertsen, E.E. Marine diatoms. In Identifying marine phytoplankton; Tomas, C.R., Ed.; Academic Press: San Diego, CA, USA, 1997; pp. 5-385.

38. Von Stosch, H.A. Pleurax, seine Synthese und seine Verwendung zur Einbettung und Darstellung der Zellwände von Diatomeen, Peridineen und anderen Algen, sowie für eine neue Methode zur Elektivfärbung von Dinoflagellaten-Panzern. Arch. Protistenkd. 1974, 116, 132-141.

39. Medlin, L.K.; Round, F.E. Taxonomic studies of marine Gomphonemoid diatoms. Diatom Res. 1986, 1, 205-225. [CrossRef]

40. Witkowski, A.; Kociolek, J.P.; Kurzydlowski, K.J. Valve ultrastructure of two new genera of marine canal-bearing diatoms (Bacillariophyceae). Phycologia 2011, 50, 170-181. [CrossRef] 
41. Lobban, C.S.; Schefter, M.; Jordan, R.W.; Arai, Y.; Sasaki, A.; Theriot, E.C.; Ashworth, M.; Ruck, E.C.; Pennesi, C. Coral-reef diatoms (Bacillariophyta) from Guam: New records and preliminary checklist, with emphasis on epiphytic species from farmer-fish territories. Micronesica 2012, 43, 237-479.

42. R Development Core Team. R: A Language and Environment for Statistical Computing, 3.5.3; R Foundation for Statistical Computing: Vienna, Austria, 2019.

43. Oksanen, J.; Blanchet, F.G.; Friendly, M.; Kindt, R.; Legendre, P.; McGlinn, D.; Minchin, P.R.; O’Hara, R.B.; Simpson, G.L.; Solymos, P.; et al. Vegan: Community Ecology Package; R Package Version 2.5-5; Creative Commons: San Francisco, CA, USA, 2019.

44. Wang, Y.I.; Naumann, U.; Wright, S.T.; Warton, D.I. mvabund-An R package for model-based analysis of multivariate abundance data. Methods. Ecol. Evol. 2012, 3, 471-474. [CrossRef]

45. Wang, Y.; Naumann, U.; Eddelbuettel, D.; Warton, D. Mvabund: Statistical Methods for Analysing Multivariate Abundance Data; R Package Version 3.13.1; Creative Commons: San Francisco, CA, USA, 2018.

46. Anderson, M.J.; Ellingsen, K.E.; McArdle, B.H. Multivariate dispersion as a measure of beta diversity. Ecol. Lett. 2006, 9, 683-693. [CrossRef] [PubMed]

47. Warton, D.I.; Wright, S.T.; Wang, Y. Distance-based multivariate analyses confound location and dispersion effects. Methods. Ecol. Evol. 2012, 3, 89-101. [CrossRef]

48. Benesh, D.P.; Kalbe, M. Experimental parasite community ecology: Intraspecific variation in a large tapeworm affects community assembly. J. Anim. Ecol. 2016, 85, 1004-1013. [CrossRef] [PubMed]

49. Majewska, R.; Gambi, M.C.; Totti, C.M.; Pennesi, C.; De Stefano, M. Growth form analysis of epiphytic diatom communities of Terra Nova Bay (Ross Sea, Antarctica). Pol. Biol. 2013, 36, 73-86. [CrossRef]

50. Polifrone, M.; Viera-Rodríguez, M.A.; Pennesi, C.; Conte, M.T.; Del Pino, A.S.; Stroobant, M.; De Stefano, M. Epiphytic diatoms on Gelidiales (Rhodophyta) from Gran Canaria (Spain). Eur. J. Phycol. 2020. [CrossRef]

51. Siqueiros-Beltrones, D.A.; Argumedo-Hernandez, U.; Landa-Cansigno, C. Uncommon species diversity values in epiphytic diatom assemblages of the kelp Eisenia arborea. Hidrobiológica 2016, 26, 61-76. [CrossRef]

52. Wuchter, C.; Marquardt, J.; Krumbein, W.E. The epizoic diatom community on four bryozoan species from Helgoland (German Bight, North Sea). Helgol. Mar. Res. 2008, 57, 13-19. [CrossRef]

53. Steinberg, P.D. Algal chemical defense against herbivores: Allocation of phenolic compounds in the kelp Alaria marginata. Science 1984, 223, 405-407. [CrossRef] [PubMed]

54. Tugwell, S.; Branch, G.M. Differential polyphenolic distribution among tissues in the kelps Ecklonia maxima, Laminaria pallida and Macrocystis angustifolia in relation to plant-defence theory. J. Exp. Mar. Biol. Ecol. 1989, 129, 219-230. [CrossRef]

55. Dubois, A.; Iken, K. Seasonal variation in kelp phlorotannins in relation to grazer abundance and environmental variables in the Alaskan sublittoral zone. Algae 2012, 27, 9-19. [CrossRef]

56. Amsler, C.D.; Amsler, M.O.; Curtis, M.D.; McClintock, J.B.; Baker, B.J. Impacts of gastropods on epiphytic microalgae on the brown macroalga Himantothallus grandifolius. Antarct. Sci. 2019, 31, 89-97. [CrossRef]

57. Toth, G.B.; Pavia, H. Intraplant habitat and feeding preference of two gastropod herbivores inhabiting the kelp Laminaria hyperborea. J. Mar. Biol. Assoc. UK 2002, 82, 243-247. [CrossRef]

58. Christie, H.; Jørgensen, N.M.; Norderhaug, K.M. Bushy or smooth, high or low; importance of habitat architecture and vertical position for distribution of fauna on kelp. J. Sea Res. 2007, 58, 198-208. [CrossRef]

59. Steneck, R.S.; Watling, L. Feeding capabilities and limitation of herbivorous Molluscs: A functional group approach. Mar. Biol. 1982, 68, 299-319. [CrossRef]

60. Thompson, R.C.; Johnson, L.E.; Hawkins, S.J. A method for spatial and temporal assessment of gastropod grazing intensity in the field: The use of radula scrapes on wax surfaces. J. Exp. Mar. Biol. Ecol. 1997, 218, 63-76. [CrossRef]

61. Johnson, C.R.; Mann, K.H. The importance of plant defence abilities to the structure of subtidal seaweed communities: The kelp Laminaria longicruris de la Pylaie survives grazing by the snail Lacuna vincta (Montagu) at high population densities. J. Exp. Mar. Biol. Ecol. 1986, 97, 231-267. [CrossRef]

62. Klochkova, T.A.; Pisareva, N.A.; Park, J.S.; Lee, J.H.; Han, J.W.; Klochkova, N.G.; Kim, G.H. An endophytic diatom, Pseudogomphonema sp. (Naviculaceae, Bacillariophyceae), lives inside the red alga Neoabbottiella (Halymeniaceae, Rhodophyta). Phycologia 2014, 53, 205-214. [CrossRef]

63. Lewin, J.; Lewin, R.A. Culture and nutrition of some apochlorotic diatoms of the genus Nitzschia. J. Gen. Microbiol. 1967, 46, 361-367. [CrossRef] 
64. Sieburth, J.M.N. Studies on algal substances in the sea. III. The production of extracellular organic matter by littoral marine algae. J. Exp. Mar. Biol. Ecol. 1969, 3, 290-309. [CrossRef]

65. Armstrong, E.; Rogerson, A.; Leftley, J.W. Utilisation of seaweed carbon by three surface-associated heterotrophic protists, Stereomyxa ramosa, Nitzschia alba and Labyrinthula sp. Aquat. Microb. Ecol. 2000, 21, 49-57. [CrossRef]

66. Armstrong, E.; Rogerson, A.; Leftley, J.W. The abundance of heterotrophic Protists associated with intertidal seaweeds. Estuar. Coast. Shelf Sci. 2000, 50, 415-424. [CrossRef]

67. Fierer, N.; Nemergut, D.; Knight, R.; Craine, J.M. Changes through time: Integrating microorganisms into the study of succession. Res. Microb. 2010, 161, 635-642. [CrossRef] [PubMed]

(C) 2020 by the authors. Licensee MDPI, Basel, Switzerland. This article is an open access article distributed under the terms and conditions of the Creative Commons Attribution (CC BY) license (http://creativecommons.org/licenses/by/4.0/). 